economist, and his desire for improved structures for basic science and education is accompanied by a strong belief that Italy must find ways of transferring knowledge of scientific advances to industry that exploit its unique cultural virtue of flexibility. "Our mentality is [one of] small groups, high energy," he says.

Most Italian industry is concentrated in small and medium-sized enterprises (5.2 million of industry's 6 million employees), which tend to be efficient but not innovative, with little interest in research. "You never find anyone on the board of an Italian company who comes from the research side", complains Prodi.

In addition, moving between public and private sectors in research is almost impossible; one cannot go to Fiat from the CNR and hope to return, because one will be viewed as a traitor, he says. Yet there is little career structure for researchers once they join industry.

Prodi has some specific proposals for closing the gap between basic research and industry. These include establishing the mutual recognition of career structures on the two sides, so that researchers can move freely between them without having to start at the bottom.

$\mathrm{He}$ also wants firmer control of Italy's new science park programme. A science park should be in the hands of a local consortium - including representatives of local industry and academics - to avoid problems that have arisen from, for example, professors "using the science parks simply as an extension of their own laboratories".

Even if Prodi were to succeed Lamberto Dini as prime minister, there is no guarantee that he would stay long enough in power to introduce the changes that he is proposing. But he is still taking science very seriously, both by visiting research institutes and consulting leading scientists. Many Italian scientists would like him to be able to do this from a position of political power.

Alison Abbott

\section{India and Russia to re-build links}

New Delhi. India and Russia last week announced an agreement to launch jointly up to 35 scientific projects at institutions in the two countries, and to create a common fund to meet the expenses of the scientists involved.

The agreement, which was signed in Moscow, represents a new start for IndoRussian scientific cooperation, which was called off after Russia's decision to cancel a rocket deal with the Indian Space Research Organization two years ago.

A space probe designed to study $\mathrm{X}$-rays from the sun and gamma radiation will be placed in Earth orbit in 1997. Other projects are primarily in areas of applied research.

K.S.Jayaraman

\title{
UK Labour Party seeks votes through pro-science image
}

London. Britain's Labour party, keen to project itself to voters as 'the party of the future', has set out to woo the scientific community with promises that science will be at the heart of the economic and social policy of any future Labour government.

John Battle, the party's science spokesman, last week promised, for example, that Labour would remedy the current lack of a strong, co-ordinated strategy for science across government, which he said resulted in initiatives by one arm of government (such as the Office of Science and Technology) often being undermined by the actions of another (such as the Department of Trade and Industry).

Battle also promised that the party would nail its colours firmly to the mast of technological change. Resurrecting the $1960 \mathrm{~s}$ pledge of the then prime minister, Harold Wilson, to forge a new Britain in "the white heat of technological

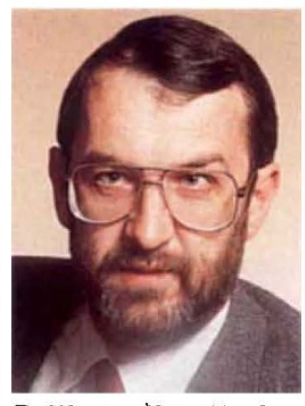

Battle: on the attack revolution", he said

Labour would distance itself from "the negative and almost anti-science cultures of the late 1970 s and 1980s".

But, in line with the party's general preelection strategy, Battle declined to be drawn on details. In particular, while attacking an overall decline in government support for research and development, he refused to make any commitments to increased funding under a Labour government, arguing that "we cannot tell what we are going inherit when we get into to power"

Nor did he make any wholesale promises about re-nationalizing research facilities, preferring to focus his criticism - and suggested alternative strategies - on the fragmented way in which the government's privatization strategy has been carried out.

Battle was speaking at the inaugural meeting of a new group called Scientists for Labour, held at the London headquarters of the labour union Manufacturing Science Finance, whose members include university and government laboratory researchers.

Opening the meeting, Willie Russell, professor of biochemistry at the University of St Andrews, said that the spur for the creation of the group had been concern about "the collapse of scientific infrastructure and a crumbling of morale in the scientific community" in Britain.

Russell said that, for him, a key turning point had been the privatization of the
British Technology Group, a body originally established to plough back into laboratories the proceeds of exploiting publicly-funded discoveries, whose success had made it "an easy target for conservative ideologues".

Matthew Freeman, a genetics researcher with the Medical Research Council in Cambridge, and a member of the executive committee of the lobby group Save British Science, emphasized the need to protect the health and integrity of the science base.

While emphasizing that his group was political neutral, Freeman added: "We have reasonably high hopes that our views coincide with those that Labour are expressing, and that we can expect more from a Labour government than we have from the conservative government of the past 10 years."

A message from Tony Blair, the Labour leader, indicated that the party - which enjoys a substantial lead in opinion polls over the ruling conservatives under Prime Minister John Major - is keen to tap into such feelings among scientists. "Science is central to the shaping of our economic, social and political future," said Blair.

Battle reinforced this message by saying that, under Blair, Labour is committed "to help people to face up to technological change and make the world a better place," and that there is a need "to ensure that science is not feared or treated dismissively".

He was more cautious about the need for any changes in the substance of science policy under a Labour government. Following the upheavals resulting from the 1993 science white paper, for example, Battle said that the Labour Party has no desire to seek a new reshuffling of the research councils.

Indeed, he admitted to the scientists' group that "many of the ideas behind the white paper were good," endorsing, for example, the principles behind the technology foresight programme - while raising questions about the commitment with which its findings are likely to be implemented.

Battle also took issue with the 'shorttermism' which, he claimed, remains "endemic to this government's attitude to science", quoting the problem of the increasing number of researchers employed on short-term contracts.

Keen to listen to scientists' complaints about the government, the Labour Party has organized six open meetings for the autumn in different cities in Britain. A lack of resources is likely to be high on the agenda. But even those who admit they are likely to be disappointed on this score suggest that the party's general attitude towards science is likely to weigh strongly. On that measure, Battle already appears to be scoring highly.

David Dickson 